\title{
III
}

\section{"Any Lady Can Do This without Much Trouble .." Class and Gender in The Dining Room (1878)}

Emma Ferry is a Senior Lecturer at the School of Art \& Design, Nottingham Trent University. Her research on domestic advice literature focuses upon Macmillan's "Art at Home" series, published between 1876 and 1883. emma.ferry@ntu.ac.uk

\section{Emma Ferry}

ABSTRACT Macmillan's "Art at Home" series (1876-83) was a collection of domestic advice manuals. Mentioned in every study of the late nineteenth-century domestic interior, they have often been interpreted, alongside contemporary publications such as Charles Eastlake's Hints on Household Taste (1868), as indicators of late 1870s home furnishing styles. Mrs Loftie's The Dining Room - 1878 - was the series' fifth book and it considers one of the home's principal (and traditionally masculine) domestic spaces. Recent research on middleclass cultural practices surrounding food has placed The Dining Room within the tradition of Mrs Beeton's Household Management (1861); however, it is not a cookery book and hardly mentions dinners. Drawing upon unpublished archival sources, this paper

Reprints available directly from the publishers

Photocopying permitted by license only

(C) Bloomsbury Publishing Plc 2014 Printed in the UK 
charts the production and reception of The Dining Room, aiming to unravel its relationships with other contemporary texts and to highlight the difficulties of using it as historical evidence. While it offers fascinating insights into contemporary taste, class and gender, this paper suggests that, as an example of domestic design advice literature, it reveals far more about the often expedient world of nineteenth-century publishing practices.

KEYWORDS: domestic advice literature, dining room, class, gender

\section{Introduction}

Published between 1876 and 1883, Macmillan's "Art at Home" series was a collection of domestic advice manuals aimed explicitly at a growing British lower middle-class readership. Devised and edited by the Reverend William Loftie (1839-1911), the series eventually encompassed subjects as diverse as Amateur Theatricals and Sketching from Nature. However, as sources for the interior design historian, arguably the most useful of the final twelve volumes are the four books that advise on aspects of the home. Rhoda and Agnes Garrett's Suggestions for House Decoration (1876); Mrs Orrinsmith's The Drawing Room (1877); Lady Barker's The Bedroom and Boudoir (1878); and Mrs Loftie's The Dining Room (1878), all offer a range of advice based on both professional and personal experiences.

These books and their illustrations are mentioned in almost every study that considers the late nineteenth-century domestic interior, where, alongside contemporary publications such as Charles L. Eastlake's Hints on Household Taste (1868) and Clarence M. Cook's The House Beautiful (1878), they have been interpreted as indicators of how people furnished their homes during the late 1870s. In 2003, written in response to these simplistic interpretations, I contributed an article to a special edition of the Journal of Design History devoted to "Domestic Design Advice" and edited by Grace Lees-Maffei. My article drew attention to the problems of using prescriptive domestic advice literature as a conventional historical source, arguing that "Advice literature may be used to provide information about the Victorian period, but it can never be treated as straightforward evidence of how people lived or furnished their homes in the past" (Ferry 2003: 16). Instead, focusing upon Suggestions for House Decoration (1876), written and illustrated by Rhoda and Agnes Garrett, I drew upon feminist literary theories to offer an analysis of their book "as a resistance to patriarchy and a subversion of Victorian domestic ideology through its demonstration of the hardwon knowledge and skills gained by England's first professional female interior decorators" (Ferry 2003: 15). In subsequent articles and book chapters I have examined other volumes in the "Art at Home" 
series, recovering the "hidden histories" of their female authors and suggesting that these advice manuals offer more information about the expedient world of nineteenth-century publishing practices than they do about the Victorian interior (Ferry 2006; 2007; 2011; 2013). More than a decade later, I remain fascinated by the women associated with the "Art at Home" series and their advice. Far from forming a homogeneous group of "Queen Anne decorators" (Neiswander 2008), these female authors, though perhaps loosely linked along class lines, wrote from completely different religious, economic, political, sexual, marital, and occupational positions, which had significant ramifications for the advice they offered. Drawing upon unpublished materials from the Macmillan Archive, this paper will chart the production and reception of Mrs Loftie's book, The Dining Room, aiming once more to highlight the difficulties of using the text and illustrations from the "Art at Home" series as historical evidence. Moreover, reading it alongside the fourth edition of Charles Locke Eastlake's Hints on Household Taste (1878), this paper will also demonstrate the central concerns of Mrs Loftie's text with contemporary constructions of class and gender. Here I suggest that, throughout The Dining Room, the upper middle-class Mrs Loftie offers advice to her imagined lower middle-class women readers and succeeds in transforming the most masculine room in the home into a feminine though not necessarily a feminist - space.

\section{The Dining Room: A Brief Historiography}

Written by Mrs Martha Jane (“Jeanie”) Loftie (1838-1914), the wife of the Reverend William Loftie, The Dining Room (1878) was the fifth book published in the "Art at Home" series (Figure 1). This was not Mrs Loftie's first foray into the literary world; when her husband had joined the staff of the Saturday Review in 1874, she also began to contribute articles to this journal, albeit anonymously. These amusing essays, which included several on housing, interior decoration, and furnishings, were eventually collected and published by Macmillan as 46 Social Twitters in 1879 (Figure 2). No doubt cashing in on the success of The Dining Room and while Mrs Loftie's name was fresh in the public mind, Social Twitters was dedicated to her husband, "without whose help these articles would never have been written" (Loftie, Mrs M.J., 1879: dedication).

Despite being the only British nineteenth-century text devoted entirely to the dining room, one of the principal (and traditionally masculine) rooms in the house, architectural and design historians have rarely drawn upon this volume to the extent that they have with the other volumes from the "Art at Home" series such as the Garretts' Suggestions for House Decoration (1876) or Mrs Orrinsmith's The Drawing Room (1877). Most scholars have simply included The Dining Room in a list of domestic advice books written during the 1870s; others have even failed to distinguish between Loftie husband and wife (Cunningham 2000: 177). Perhaps this confusion 


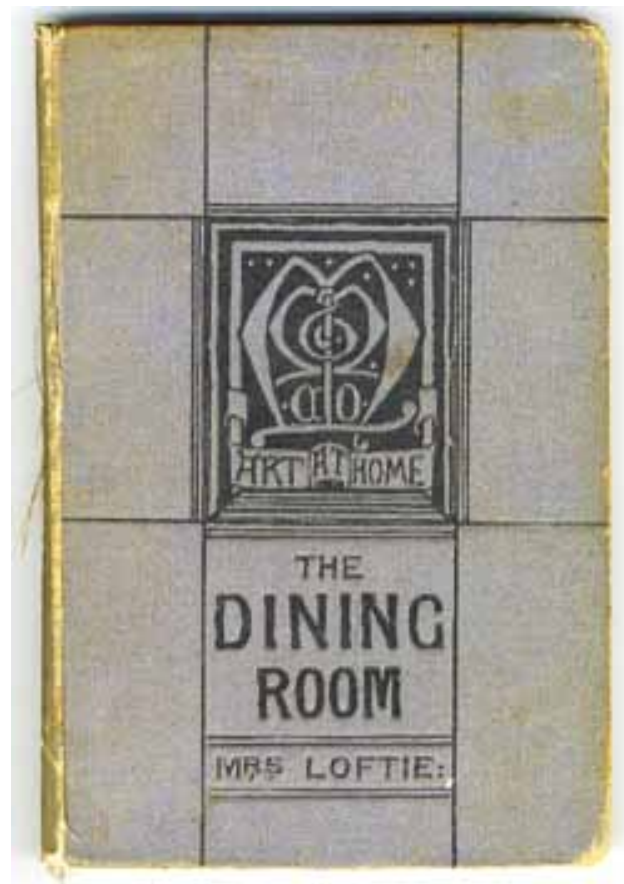

Figure 1

The front cover of Mrs Loftie's The Dining Room in Macmillan's "Art at Home" series, edited by the Rev. W.J. Loftie, published by Macmillan \& Co., 1878.

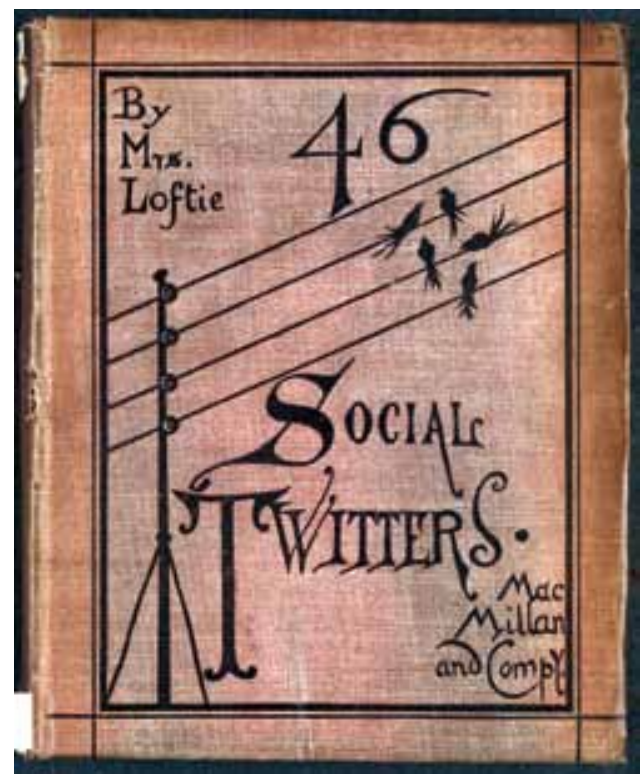

Figure 2

The front cover of Mrs Loftie's 46 Social Twitters, published by Macmillan \& Co., 1879; cover designed by Mr Harvey Orrinsmith. 
is caused by W.J. Loftie's "Editor's Preface" to The Dining Room, which repeats Thackeray's dictum that "the dinner at home ought to be the centre of the whole system of dinner-giving" (Loftie, Rev. W.J., 1878: i). Recent research (Rich 2003) on middle-class cultural practices surrounding food and dining has placed The Dining Room within the tradition of Mrs Beeton's Household Management (1861), but it is important to note that Mrs Loftie's text is not a cookery book: there are no recipes and despite its title, The Dining Room, barely mentions dinners.

The Dining Room receives slightly more attention in Judith Neiswander's Ph.D. thesis (1988), recently published as The Cosmopolitan Interior: Liberalism and the British Home, 1870-1914 (2008). However, here images from the "Art at Home" series are used throughout as straightforward visual evidence of "Queen Anne décor" (Neiswander 2008: 123); moreover, biographical inaccuracies, which lead Neiswander to link the Loftie couple with the Garrett cousins, go some way to undermine her "Liberal" interpretation. Belonging to a class of Protestant Anglo-Irish landowners from Ulster, it is more likely that the Reverend and Mrs Loftie would have held a Conservative or Liberal Unionist position. Politically, Mrs Loftie's first husband, J.J. Burnett, was known to be "consistently Conservative, and supported the interests of his party with tact and firmness" (Ayr Observer 1862: 5), while William Loftie, an Irish Anglican clergyman, is unlikely to have supported Gladstone's Liberal government, which had disestablished and disendowed the Church of Ireland in 1869. Significantly, Mrs Loftie, one of the "104 ladies, well known in Westend drawing-rooms" (Blackburn 1902: 178) who were the original signatories of Mrs Humphry Ward's infamous article "An Appeal against Female Suffrage" (1889), certainly did not share the Garrett family's feminist views. These divergent views indicate the different perspectives from which the female authors contributing to the "Art at Home" series were writing and challenges the appearance of homogeneity that surrounds these texts. This is a similarity further contradicted when the production of The Dining Room is considered in detail.

\section{The "Art at Home" series: Producing Advice}

The production of the entire "Art at Home" series can be traced through the correspondence collated in the General Letterbooks and other collections of letters held in the Macmillan Archive at the British Library and Reading University. The letters outline the initial plan for the series, record the commissioning of authors, illustrators, engravers, and bookbinders, and chart the progress of the volumes as they were written - or in some cases remained unwritten. They also provide an insight into the marketing techniques employed, refer to reviews, and indicate the overall success of the venture.

As I noted in 2003, Rhoda and Agnes Garrett's Suggestions for House Decoration (1876) was among the first four books in 
the series. The illustrations were produced by one or both of the cousins and show examples of their furniture designs. However, the Macmillan letters reveal that the book that would eventually become The Dining Room was written and illustrated in a very different manner. Initially proposed by William Loftie in March 1877 as "Art at Table," this volume was "to include both cooking \& also some simple rules of good taste for the decoration of the dinner table, the choice of cups \& saucers \& crockery in general." Interestingly at this stage, he added: "No author competent to undertake this book has occurred to me" (BL: Add. MS 55075/122-8). Serendipitously, the "Art at Home" series was to expand rapidly later the same month, when Clarence M. Cook, author of a series of illustrated articles on house furnishing published in the American journal Scribner's Monthly, wrote to Frederick Macmillan offering him the British publication rights. Frederick Macmillan wrote to Loftie asking him to:

look at the articles on "Beds, Stools, Candlesticks" in the accompanying numbers of Scribners Magazine. They are by Clarence Cook an American art critic who has a passion for furnishing and collecting pretty things.

These papers are to be collected \& published as a book in America \& have been offered to us for England. My impression is that the text would require a great deal of editing \& rewriting to suit it to our somewhat different conditions, but that this might be worth doing. However I should like to have your opinion on it (BL: Add. MS 55402/351).

One wonders what the Anglo-Irish Loftie made of the abhorrent comments written by Cook, where he blamed "the Biddy tribe from the bogs of Ireland" for a long list of social ills (Cook 1878: 271). It appears that on Loftie's advice Macmillan refused Cook's proposal, explaining that his articles "would not be suitable for English sale." However, he suggested that Macmillan \& Co. instead "buy the very beautiful illustrations \& ... re-cast or re-write the text so as to suit it to English requirements" (BL: Add. MS 55402/372), and after brief negotiations, Macmillan \& Co. bought electrotypes of the original engravings from Scribner's for £100 (BL: Add. MS 55402/752). Letters in the Macmillan Archive indicate that this happy solution was in fact suggested by Mrs Loftie. Two days after Cook's original proposal was refused, Alexander Macmillan wrote: "I shall be so glad to hear about Mrs Loftie's idea of the Dining \& Drawing Room" (BL: Add. MS 55402/392). Mrs Loftie's idea quickly became a reality. Before the electroplates had even crossed the Atlantic, she had begun The Dining Room, while letters to her husband from George Lillie Craik, a partner at Macmillan and Co., indicate that both Lady Barker and Mrs Orrinsmith, having been shown copies of Cook's original articles, were equally confident that they could produce suitable texts, which later became The Bedroom and Boudoir and 
The Drawing Room respectively (BL: Add. MS 55402/954; BL: Add. MS 55403/306). These three volumes were all written and published, complete with their American illustrations, between 1877 and 1878, and my comparison of The House Beautiful with the "Art at Home" books in Aynsley and Forde's (2007) Design and the Modern Magazine reveals the different approaches Mrs Orrinsmith, Lady Barker, and Mrs Loftie took when writing around these images (Ferry 2007).

Mrs Loftie's attitude toward the images reveals several strategies. The Dining Room comprises seven chapters: the awkwardly named "Of Feeding Rooms in General"; "The Dining Room"; "Sideboards, Tables and Chairs"; "The Parlour"; two chapters on "Laying the Table"; and a final chapter on "Flowers and Fruit" - this section being largely derived from articles Mrs Loftie had previously published in the Saturday Review (Loftie 1875: 245-6; Loftie 1876: 266-7). The book contains forty-three illustrations, including Mrs Loftie's personal insignia and motto, Prend moy tel que je suis (take me such as I am) (Figure 3), and her design for marking linen, formed from her initials, her personal motto, and the year in which The Dining Room was written (Figure 4). Designed as a monogram or "signature," this linen mark appears on the first page of The Dining Room. Neiswander states that the prominence of Mrs Loftie's monogram characterizes the "challenging attitude of the Queen Anne writers and decorators as a group" (Neiswander 2008: 126). However, I suggest that the inclusion of these personal designs, acting as stamps of authority, suggests anxieties about both authorship and ownership - concerns which result from the way in which the book was written and illustrated.

The majority of the forty-three illustrations in The Dining Room were taken from Clarence Cook's articles for Scribner's Monthly. In contrast, Cook's chapter on "The Dining Room," as it appeared

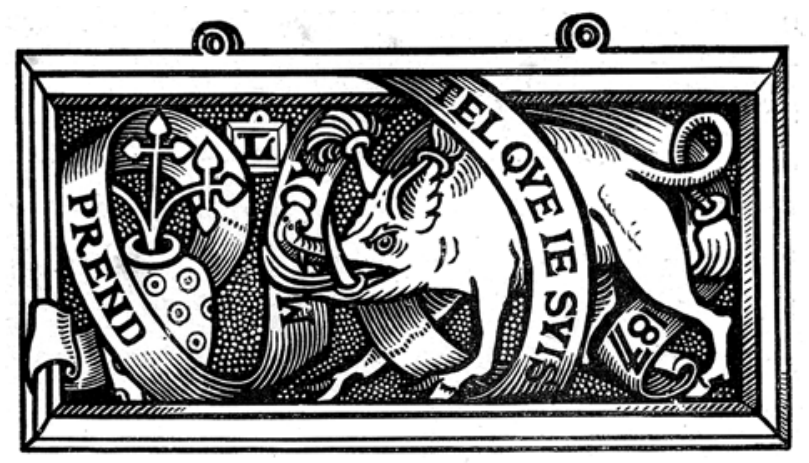

Figure 3

Mrs Loftie's insignia: Prend moy tel que je suis (Take me such as I am), labeled as "Design for carved panel," from Mrs Loftie's The Dining Room in Macmillan's "Art at Home" series, edited by the Rev. W.J. Loftie, published by Macmillan \& 


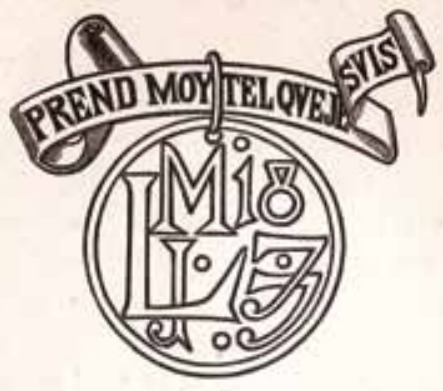

\section{THE DINING-ROOM.}

\section{CHAPTER I.}

OF FEEDING ROOMS IN GRNERAL.

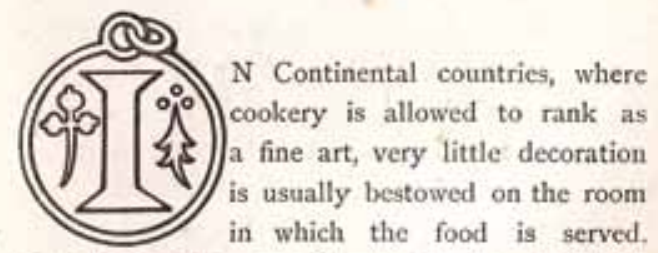

Four bare walls, a polished floor, the inevitable looking-glass, with its reflected clock, and the necessary table and chairs seem to satisfy people of moderate pretension. The most important considerations connected with the salled-mangor are not of the pattern of the carpet, the height of the

I.OF.

B

Figure 4

A Design for a Linen Mark, from Mrs Loftie's The Dining Room in Macmillan's "Art at Home" series, edited by the Rev. W.J. Loftie, published by Macmillan \& Co., 1878, chapter 1, p. 1.

in The House Beautiful (1878), contained only sixteen illustrations. Throughout The Dining Room, particularly in the third chapter on "Sideboards, Tables and Chairs," Mrs Loftie made constant references to the Scribner's images, renaming and adapting them as she saw fit. Thus, the illustration that Cook described as "a group of pieces of furniture, all of it belonging to Old Colony times, drawn by Mr. Lathrop for Bryant \& Gay's 'History of the United States'” (Cook 1876: 94) was redefined by Mrs Loftie as "probably either 
of old Dutch manufacture, or is imitated from it" (Loftie 1878: 56). On several occasions, against the advice of Frederick Macmillan, Mrs Loftie even used the American illustrations as examples of bad taste (BL: Add. MS 55404/387). Thus, having quoted at length from an article on the faults of fashionable knick-knacks and ornaments, she described an image of an ornately carved and painted table as "An example of the sort of furniture designed on the same false principles as these horrible inventions" (Loftie 1878: 19). The illustration list described this woodcut as "AN EXAMPLE TO BE AVOIDED." Yet, when this woodcut of a "Table and Chair from Tyrol, Bavaria," which had itself been copied from an engraving in M. Rodolphe Pfnor's Ornamentation Usuelle (1866-7), appeared in the tenth of the original articles in Scribner's Monthly, it was described in detail and judged to be "very pretty" (Cook 1877: 820). (Figures 5a and 5b)

In The Dining Room, the Scribner's illustrations are supplemented by three full-page woodcuts that resemble pages from contemporary

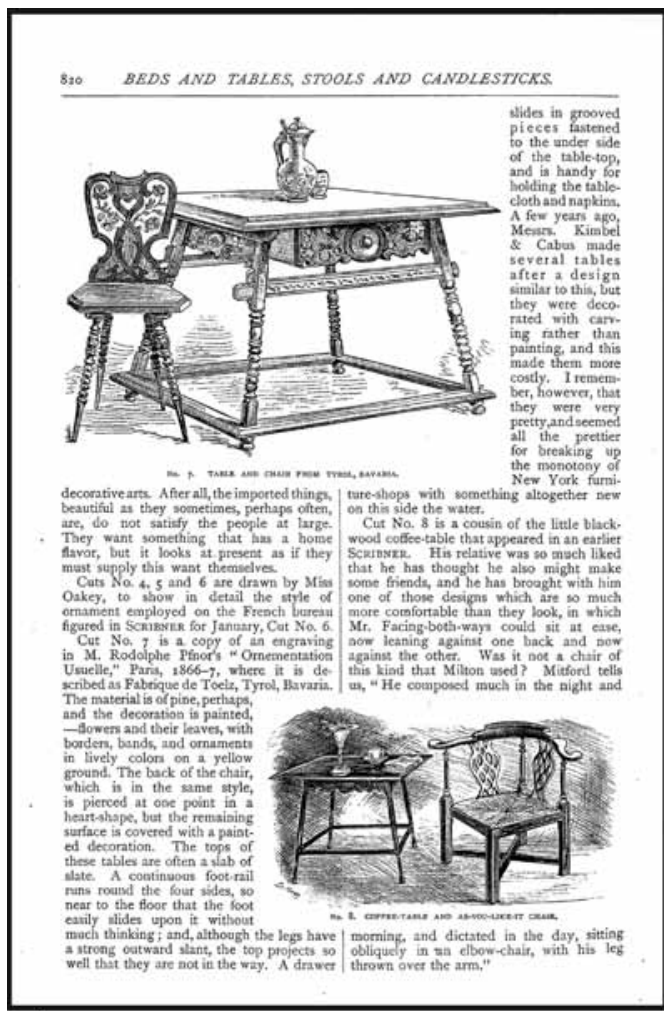

(a)

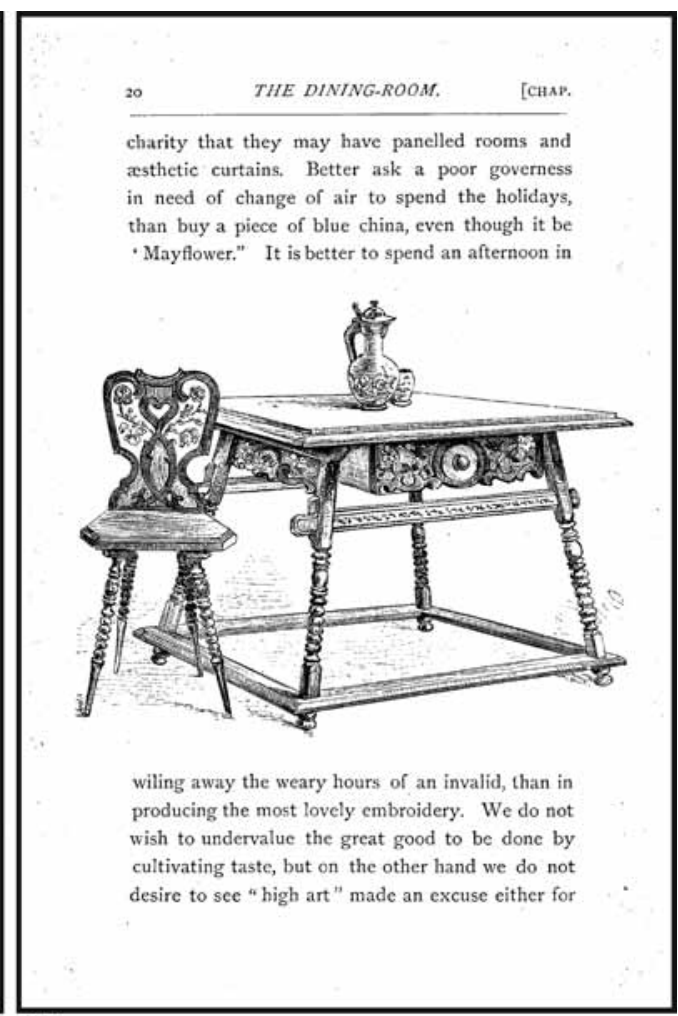

(b)

Figure 5

(a) Cook's "very pretty" "Table and Chair from Tyrol, Bavaria," from "Talk Here and There: Beds and Tables, Stools and Candlesticks, X." Scribner's Monthly, 13, p. 820. (b) Mrs M.J. Loftie's "An Example to Be Avoided," from The Dining Room in Macmillan's "Art at Home" series, edited by the Rev. W.J. Loftie, published by 
trade catalogs and to which Mrs Loftie makes frequent reference. The correspondence also indicates that Mrs Loftie had proposed color printing of these illustrations, which Macmillan rejected, commenting:

The impracticality of your idea outweighs its prettiness and usefulness. This colour-printing is dreadfully expensive, some such scheme has been before us more than once, but has always fallen through on the ground of cost. We were told once by an authority on the subject that it would require 80 printings to give a proper idea of the best colours!! I am sorry we do not see our way to acting on your suggestion. (BL: Add. MS 55403/604)

These three full-page illustrations give examples of "Lambeth Ware," by kind permission of Messrs Doulton; "Specimens of Table Glass," by kind permission of Messrs Powell; and "Dinner Ware, Lamps, Dessert Dishes, Wine-Glasses, \&c." A small table designed by the Garrett cousins also appears in this last rather cluttered page of illustrations (Figures $6 \mathrm{a}-\mathrm{c}$ ). The correspondence relating to the production of The Dining Room also indicates a tension between advice and advertising. After reading Mrs Loftie's text at the beginning of December 1877, Frederick Macmillan wrote:

I read through the sheets of Mrs Loftie's capital little book yesterday and was much interested by it. There are however a good many references to London tradesmen which would certainly be very useful, but which in deference to a censorious world ought, I think to be omitted. It is necessary to be very careful about such things especially as we are in the habit of inserting these very tradesmen's advertisements at the end of the volumes. This objection to such references would not strike you or Mrs Loftie, but I have spoken to the people here about it and they all fully agree with me that in a book like this no names of existing tradesmen should be mentioned. (BL: Add. MS 55404/387)

Consequently, with the exception of a reference to "the style of colouring employed by Mr. Morris and his school" (Loftie 1878: 13) and a comment on Doulton's Lambeth pottery, any recommendations for contemporary retailers or manufacturers were removed from The Dining Room, though a full-page advertisement for John Mortlock's Pottery Galleries was included at the back of the book.

Printed by Clay \& Sons in December 1877, The Dining Room was issued in January 1878. It was reprinted in July 1878: in total 5,000 copies were produced. A lengthy review for The Dining Room, titled "Art in the Dining Room," appeared on January 12, 1878 in the Saturday Review, where having agreed with Mrs Loftie's comments 


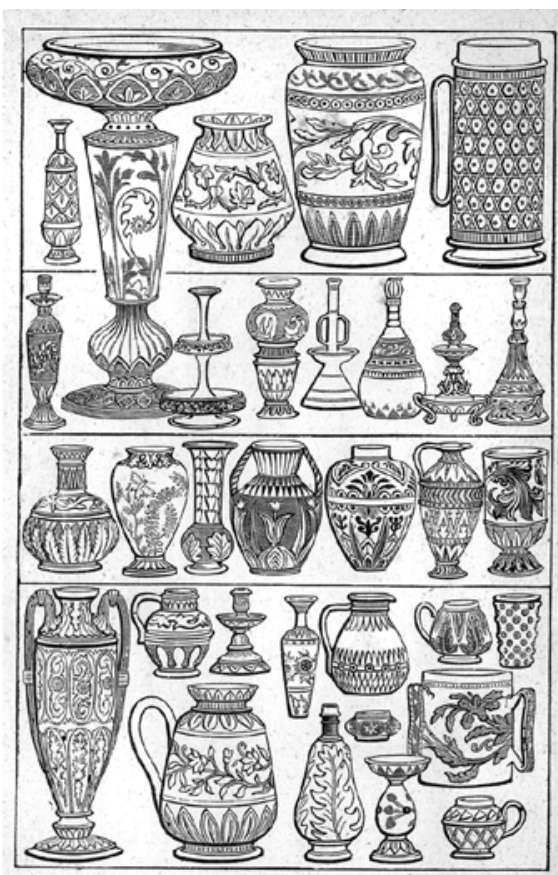

(a)

(b)

LAxastr Whrk.

Frowt.

(c)
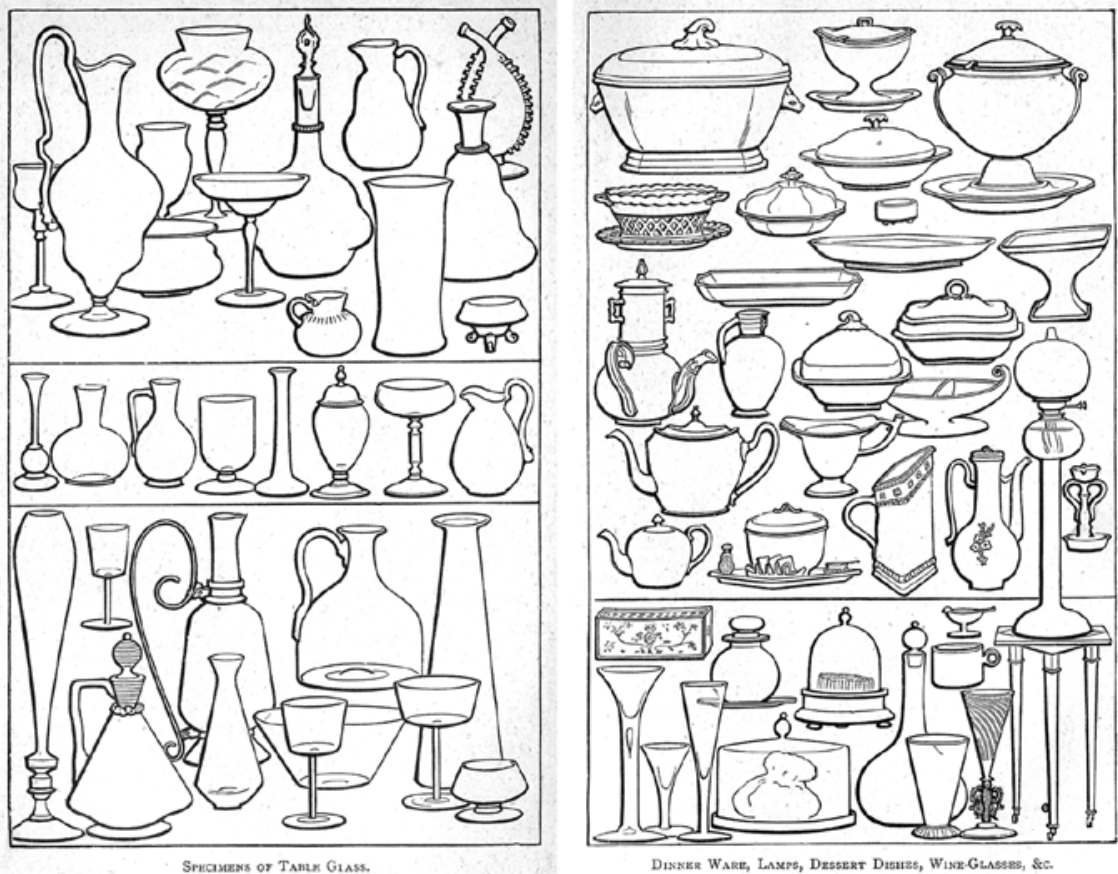

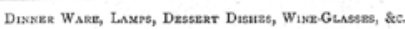

Figure 6

(a) "Lambeth Ware" by kind permission of Messrs Doulton. (b) "Specimens of Table Glass" by kind permission of Messrs Powell. (c) "Dinner Ware, Lamps, Dessert Dishes, Wine-Glasses, \&c." Parts (a)-(c) reproduced from Mrs Loftie's The Dining Room in Macmillan's "Art at Home" series, edited by the Rev. W.J. Loftie, published 1878. 
on the vagaries of fashions for "medieval" dining room schemes, Venetian glass, and Japanese objects, the reviewer remarked:

If this manual prevents well-disposed persons, who really feel a call to be decorative but have no more taste than churchwardens, from rushing blindly into purchases of Venetian glass, it will not have been written in vain. (Saturday Review 1878: 41)

Having recycled the Scribner's illustrations, Mrs Loftie also "borrowed" large sections of the text. A close reading indicates that The Dining Room contains several lengthy quotations from a wide range of sources: more than a quarter of the first chapter had previously appeared elsewhere. These borrowings include a quote from William Bellars' (1876) The Fine Arts and Their Uses; a poem from R.E.E. Warburton's (1833) A Looking-glass for Landlords; an extract from an article criticizing knick-knacks from "one of the weekly papers" (Loftie 1878: 16); and "a letter from an old lady" (Loftie 1878: 21) that mocks "artistic" dining. Given that Mrs Loftie used footnotes when quoting from published sources, it seems likely that these last two extracts are her own work. In later chapters Mrs Loftie quoted from the diaries of Samuel Pepys and John Evelyn; George Cavendish's Life of Cardinal Wolsey; the Libellus de Admirandi Beati Cuthberti; the sermons of Archbishop Whateley; and a passage by Mrs Gaskell. She also repeated the Garretts' advice on dining chairs from Suggestions for House Decoration; recommended Mrs Orrinsmith's The Drawing Room for a discussion of the peculiarities of the modern piano; and noted that "The question of the best way to hang pictures has been fully discussed in A Plea for Art at Home [sic; incorrect title]" (Loftie 1878: 79-80).

As has been noted, the process of producing The Dining Room indicates that Mrs Loftie's contribution to the series offers more information about the expedient world of nineteenth-century publishing practices than it does about the Victorian interior. Nonetheless, a brief comparison with the 1878 edition of Charles Eastlake's Hints on Household Taste demonstrates that The Dining Room remains an important source for studying nineteenth-century discourses about class and gender in the home.

\section{"The Lady of the House": Feminizing Masculine Space}

Like The Dining Room, the fourth edition of Hints on Household Taste was also published in 1878. Elsewhere I have suggested that its earlier editions provided a model for the authors of the "Art at Home" series (Ferry 2007), and Mrs Loftie drew on this "father-text." Her chapter on "The Dining Room" consistently replicates Eastlake's advice and comments on similar subjects. Both authors, for example, condemn the infamous "telescope table" and offer similarly critical comments on contemporary dinnerware; they also censure 
fashionable knick-knacks, both being particularly offended by the crazes for cupids and wheelbarrows (Eastlake 1878: 288; Loftie 1878: 16).

However, Mrs Loftie is far more concerned with the social functions of the dining room and the objects used and displayed therein. This is an aspect that Eastlake does not explore fully until the final three chapters of Hints, in which he advises upon "Crockery," "Table Glass," and "Plate and Cutlery." His last chapter notes that:

A well-appointed dinner-table is one of the triumphs of an English housewife's domestic care. That the cloth shall be of fine and snow-white damask; that the decanters and wineglasses shall be delicate in form and of purest quality; that the silver shall look as bright and spotless as when it first came wrapped in tissue-paper from the silversmith's; that the épergne shall be filled with choicest flowers - these are the points which she will consider of as much importance as the dainty skill of the cook's art itself. (Eastlake 1878: 282)

And it is this "well-appointed dinner-table" and the "housewife's domestic care" that form the real focus of Mrs Loftie's book; indeed, both authors consider the merits of three- or four-pronged forks, but while Eastlake focuses on the design of cutlery and plate, Mrs Loftie explains how to clean the silver. In suggesting different ways in which the dining room could function and in prioritizing these decorative objects - and their upkeep - I propose that she attempts to alter the gender identity of this room. Here Mrs Loftie's emphasis is upon the feminine - upon a process of feminization. This is a different approach to the feminist methods adopted by the suffragist Garrett cousins, who presented their readers with the Paterfamilias ensconced in his modern London Dining Room, resisting all change:

Yet there is no other room in the house where innovations are more grudgingly permitted, and an Englishman would suspect you of every other revolutionary tendency, if you proposed any radical changes in the colour of the walls, or in the forms and arrangements of the furniture. (Garrett 1876: 43)

The dining room has traditionally been considered as a masculine space, as is best demonstrated by Juliet Kinchin's essay "The Gendered Interior" (1996). Drawing on Robert Kerr's The Gentleman's House (1864), which suggests that "the whole appearance of the room ought to be that of masculine importance" (Kerr 1864: 94), Kinchin considers the "explicit contrast between the 'masculine' dining room and the 'feminine' drawing room" (Kinchin 1996: 12). However, the lower middle-class dining room that Mrs Loftie describes is far closer to the domestic space that Kerr designates the "Parlour Dining Room," which: 
ought to be modified from that of a more regular Dining Room; so that feminine attributes may be, according to circumstance, duly represented. In a word, the arrangements are to be such as shall preserve as far as possible the characteristics of the proper Dining Room, and at the same time admit those of an informal Drawing-room or Parlour. (Kerr 1864: 103)

Significantly, one of the chapters in The Dining Room is titled "The Parlour," which shifts the focus even further away from dining. Here, Mrs Loftie considers this dual-purpose parlor-dining room, which of necessity would "be considered chiefly as a sitting-room" (Loftie 1878: 71). She comments:

In households where there are grown-up sons and daughters living at home, it is very nice if each one can be given a little corner of their own in the family parlour - a place to write or draw, or read, or put by their work. They can be helped to make it pretty and convenient, and to keep it neat. We are here especially speaking of families whose staff of servants is not sufficient to allow the young people to have fires in their bedrooms, and they are consequently obliged to sit together to follow their various avocations. (Loftie 1878: 77-8)

Thus, the imagined class and financial position of the readership makes this room a multifunctional family space. Indeed as Jane Hamlett (2009), who has reexamined the relationship between the gendered hierarchies of the middle-class home, comments:

In everyday practice, most middle class families were unlikely to have the resources to carry out elaborate gendered segregation in their homes. (Hamlett 2009: 579)

This can be discerned throughout The Dining Room in the emphasis Mrs Loftie places on its use by all members of the family; particularly in the introduction of young children into a space usually considered the preserve of Paterfamilias. Here the dining room is transformed into a nursery and schoolroom where the younger members of the family could learn a range of social and practical skills and knowledge under their mothers' guidance. Indeed, much of Mrs Loftie's advice relates to the acquisition of knowledge, "the resource of cultural capital," which, as Linda Young in her study of Middle-class Culture in the Nineteenth Century has noted, is most effectively learned at "mother's knee" (Young 2003: 5). Thus, Mrs Loftie suggested that "children ought to be taught the 'poetry of service', and encouraged to forestall the wants of their elders with quiet intelligence and politeness" (Loftie 1878: 36) and that it was "necessary as well as most desirable to insist upon extreme punctuality with regard to children at their meals" (Loftie 1878: 27). Mrs Loftie even suggested that a space might be found where: 
children must be allowed, without fear of spoiling nice furniture, to practise some of the details of housekeeping, which in these days are rarely taught, although a knowledge of them is more than ever required. To boys intending to emigrate even a slight acquaintance with the elementary principles of cooking would be found invaluable. (Loftie 1878: 7)

She also suggested that young people might even experiment with decoration:

Parents who complain that they do not know how to keep their children quiet when bad weather obliges them to stay indoors, have never tried the fascinations of a little Art at Home. (Loftie 1878: 8-9)

Significantly, the only "children" that Eastlake mentions are women, whose lack of taste he equates with childishness. Bemoaning the use of varnish on dining room furniture, he likens novelty-driven female consumers to children:

The ladies like it best when it comes like a new toy from the shop, fresh with recent varnish and untarnished gilding. And they are right; for in this transient prettiness rests the single merit which it possesses. (Eastlake 1878: 83)

In contrast, Mrs Loftie comments upon men who lack the knowledge which mothers could impart to their children in the dining room. She wrote:

When luncheon is also the children's dinner-time we would especially plead for care in the decoration of the table. If living in the country they will help by gathering and arranging flowers, and by hunting for grasses and coloured leaves in the woods when the garden is bare ... In this way they will learn the names of common plants which really ought not to be omitted from the education of any child. It is sometimes surprising the ignorance of grown-up clever men about the simple plants and trees of their own country. (Loftie 1878: 35-6)

Here, the introduction of Nature into the dining room also brought the feminine into this masculine space: "flowers and fruit are at all times desirable on the table" (Loftie 1878: 34). If "Female Is to Male as Nature Is to Culture" (Ortner 1972), then perhaps it is significant that Mrs Loftie's final chapter, based largely on articles previously published in the Saturday Review, was titled "Flowers and Fruit." This section described old-fashioned gardens; flower arranging for the dinner table; designs for vases and flowerpots; growing fruit for desserts; and recommendations for suitable and affordable wine. 
Here, Nature is positioned in the dining room in the form of floral arrangements and fruit for dessert as [feminine] objects to be consumed or displayed upon the [masculine] dining table in addition to the items described in two chapters titled "Laying the Table."

Linda Young has commented that "dining was one of the earliest expressions of genteel self-control in the form of cutlery and table napkins" and that "the ceramic and glass equipage of the table for formal dining constituted yet further sites for the simultaneous display of conspicuous consumption" (Young 2003: 181-2). However, given the class status of her imagined readers, Mrs Loftie advocates inconspicuous consumption, recommending and illustrating simple and inexpensive designs for glass and china suitable for the lower middle-class parlor dining room:

We have succeeded in imitating Venetian glass in a very satisfactory manner, as may be seen in many show-rooms, but the ordinary table glass is what we are at present concerned with. By kind permission we give the outlines of a few patterns. We have chosen the least expensive specimens. (Loftie 1878: 96-7)

From start to finish, The Dining Room is a text largely concerned with the class status and inconspicuous consumption of Mrs Loftie's imagined female readers. Her husband's Preface addresses "inexperienced housekeepers of small income" (Loftie, Rev. W.J., 1878: vii) and on the very last page Mrs Loftie advises that:

With a limited income much time must be given by the lady of the house to small details if it is her ambition to have dainty dishes daintily served. She must not be ashamed of being seen in a cooking apron or with a duster in her hand. (Loftie 1878: 128)

Similarly, when advising on the arrangement of dust-covers to protect soft furnishings, she comments that "any lady can do this without much trouble" (Loftie 1878: 75-6), thus suggesting that servants were not always required even if they were desired as indicators of middle-class status. Indeed, much of her advice dwells on the problem of managing servants. Mrs Loftie, both in The Dining Room and in her articles for the Saturday Review, was deeply critical of domestic servants. Throughout The Dining Room servants are described as "clumsy," "careless," and "lazy," and there were constant references to breakages and mistreatment of household objects:

Careless servants force their employers to eat a fair portion of the proverbial "peck of dirt" in the saltcellars, as anyone can prove by looking at a table which has on it even one day's dust. (Loftie 1878: 104) 
Emphasizing contemporary anxieties about household hygiene, those with slipshod servants were told to "show them we care enough about order and cleanliness to take the trouble to secure it with our own hands if necessary" (Loftie 1878: 128). In contrast, those "families whose staff of servants is not sufficient" (Loftie 1878: 79) were offered solutions that enable them to serve themselves:

In every dining room there ought at all times to be the possibility of boiling water, heating soup, or making coffee, by fire, spiritlamp, or gas. Many people with few servants allow themselves and their visitors to be most unnecessarily uncomfortable because they will not adopt little inventions which would enable them at small trouble to prepare things for themselves. (Loftie 1878: 27-8)

Mrs Loftie would later write Comfort in the Home (1895), a book aimed explicitly at female servants (though of course bought by their mistresses), but in The Dining Room her constant references to the lack of servants can be interpreted as a variation on the numerous allusions to the inappropriate class aspirations and the moderate means of the lower middle-class reader:

As we are not writing for those wealthy people who can go into a shop, and order whatever strikes their fancy at the moment, nor yet have undertaken to treat of dinner parties as distinct from the family meal. (Loftie 1878: 95)

\section{Conclusions}

Linda Young has commented that "the family dinner contains ancient meanings of patriarchal authority in which the head of the household demonstrates his ability to provide his family with food" (Young 2003: 180). However, having literally dismantled the dominant dining table and transformed this masculine space into a family parlor, in these last three chapters Mrs Loftie ignores dining and instead celebrates the housekeeping skills of the lady of the house, emphasizing feminine activities including the cleaning of crockery, the polishing of plate, and the laundering and labeling of linen. And, perhaps this explains why Mrs Loftie's book remains one of the least considered volumes in the "Art at Home" series. Written around illustrations from Scribner's Monthly and composed of quotes from a range of other sources, The Dining Room is a problematic source for historians of the domestic interior. With its emphasis on limited incomes, inconspicuous consumption, and managing without servants, it is an example of advice literature largely concerned with the class status of its imagined readers. However, read alongside Hints, it is possible to discern the ways in which Mrs Loftie both replicates and subverts Eastlake's masculine discourse. In advocating the home production of decorative and natural objects for the table, 
she installs the Materfamilias of the lower middle class in a dining room filled with children, female activity, and Nature and transforms the most masculine room in the "gentleman's house" into a feminine space.

\section{References}

"Art in the Dining Room." 1878. Saturday Review, XLIV: 41-2.

Ayr Observer, The. 1862 (March 25), 5.

Blackburn, Helen. 1902. Women's Suffrage: A Record of the Women's Suffrage Movement in the British Isles. London: Williams \& Norgate.

British Library Manuscripts Collection: Macmillan \& Co Ltd., publishers, 1833-1969: Add. MSS 54786-56035, 61894-6.

Cook, Clarence M. 1876. "Fire-places, Book-cases, etc: Beds and Tables, Stools and Candlesticks, VII." Scribner's Monthly, 13: 1.

Cook, Clarence M. 1877. "Talk Here and There: Beds and Tables, Stools and Candlesticks, X." Scribner's Monthly, 13: 6.

Cook, Clarence M. 1878. The House Beautiful. New York: Scribner, Armstrong \& Co.

Cunningham, Colin. 2000. "Hints on Household Taste and The Art of Decoration: Authors, Their Audiences and Gender in Interior Design." In Joan Bellamy, Anne Laurence, and Gill Perry (eds), Women, Scholarship and Criticism: Gender and Knowledge, c. 1790-1900. Manchester: Manchester University Press.

Eastlake, Charles Locke. 1878. Hints on Household Taste. London: Longman \& Co.

Ferry, Emma. 2003. “'Decorators May Be Compared to Doctors': An Analysis of Rhoda and Agnes Garrett's Suggestions for House Decoration (1876) ..." Journal of Design History, 16(1): 15-33.

Ferry, Emma. 2006. "Home and Away: Domesticity and Empire in the Work of Lady Barker." Women's History Magazine, Autumn: 4-12.

Ferry, Emma. 2007. "“... information for the ignorant and aid for the advancing ...' Macmillan's 'Art at Home Series,' 1876-1883." In Jeremy Aynsley and Kate Forde (eds), Design and the Modern Magazine. Manchester: Manchester University Press.

Ferry, Emma. 2011. "'The Other Miss Faulkner': Mrs Orrinsmith and the 'Art at Home Series.'” The Journal of William Morris Studies, XXIII(3): 47-64.

Ferry, Emma. 2013. "Writing Home: The Colonial Memories of Lady Barker, 1870-1904." In Penny Sparke and Anne Massey (eds), Biography, Identity and the Modern Interior. Farnham: Ashgate, 53-6.

Garrett, Rhoda, and Garrett, Agnes. 1876. Suggestions for House Decoration in Painting, Woodwork and Furniture. London: Macmillan \& Co.

Hamlett, Jane. 2009. "The Dining Room Should Be the Man's Paradise, as the Drawing Room Is the Woman's': Gender and 
Middle-class Domestic Space in England, 1850-1910." Gender \& History, 21(3): 576-91.

Kerr, Robert. 1864. The Gentleman's House or, How to Plan English Residences from the Parsonage to the Palace. London: John Murray.

Kinchin, Juliet. 1996. "The Gendered Interior.” In Pat Kirkham (ed.), The Gendered Object. Manchester: Manchester University Press.

Loftie, Mrs Martha Jane. 1875. "Queen Anne's Flowers." Saturday Review, XXXIX: 245-6.

Loftie, Mrs Martha Jane. 1876. "Modern Gardens." Saturday Review, XLI: 266-7.

Loftie, Mrs Martha Jane. 1878. The Dining Room. London: Macmillan \& Co.

Loftie, Mrs Martha Jane. 1879. 46 Social Twitters. London: Macmillan \& Co.

Loftie, Mrs Martha Jane. 1895. Comfort in the Home. London: Leadenhall Press.

Loftie, Rev. William J. 1878. "Preface." The Dining Room. London: Macmillan \& Co.

Neiswander, Judith A. 1988. "Liberalism, Nationalism and the Evolution of Middle-class Values: The Literature of Interior Decoration in England, 1875-1914." Ph.D. thesis, Westfield College, University of London.

Neiswander, Judith A. 2008. The Cosmopolitan Interior: Liberalism and the British Home, 1870-1914. London: Paul Mellon Centre for Studies in British Art, Yale University Press.

Ortner, Sherry B. 1972. "Is Female to Male as Nature Is to Culture?" Feminist Studies, 2(Fall): 5-31.

Reading University Library: Macmillan \& Co Ltd, publishers, 18751964: MS 1089.

Rich, Rachel. 2003. "Designing the Dinner Party - Advice on Dining and Décor in London and Paris, 1860-1914." Journal of Design History, 16(1): 49-61.

Ward, Mrs Humphry. 1889. "An Appeal against Female Suffrage." Nineteenth Century, 25: 781.

Young, Linda. 2003. Middle-class Culture in the Nineteenth Century: America, Australia and Britain. Basingstoke: Palgrave. 
